Editorial Office: Rectorate Building, Floor V, Jl. Prof. Dr. Sumantri Brojonegoro No. 1 Bandar Lampung, 35145, INDONESIA

Mobile: +62 813-6741-6145, Phone/Fax +62 721702767

Email: jassp@kpa.unila.ac.id, Website: https://jassp.lppm.unila.ac.id

Volume 1, Number 1, May 2021

\title{
Single Mothers in Malaysia: Survivability, Entrepreneurship and Empowerment
}

\author{
Muhammad Suhaimi Mohd Yusof, ${ }^{1}$ Mohd Khirul Azwan Mohd Kamal, ${ }^{1}$ Muhammad Safwan Mohd Yusof ${ }^{2}$ \& \\ Nur Ain Yusof ${ }^{2}$ \\ ${ }^{1}$ Ghazali Shafie Graduate School of Government, Universiti Utara Malaysia \\ ${ }^{2}$ Othman Yeop Abdullah Graduate School of Business, Universiti Utara Malaysia \\ Correspondence: Muhammad Suhaimi Mohd Yusof, Ghazali Shafie Graduate School of Government, Universiti \\ Utara Malaysia. E-mail :samyusof9889@gmail.com
}

Received: April 5, 2021 Accepted: May 11, 2021 Online Published: May 17, 2021

\begin{abstract}
The incidence of single-parent families has been rising continuously where the divorce has become a popular solution for people in seeking the final clarity towards the marriage problems. This figure is consistent with the current trend worldwide upon this topic of single mothers. An enormous increase in the number of single mothers due to divorce has become a reasonable approach for the people in seeking the final clarity towards the marriage problems. In Malaysia, single mothers can be classified as in two variables which are parental death and spousal separation or divorce; parenting is a tough job without a spouse helping in a child's development. The incidence of single-parent families has been rising continuously where the divorce has become a popular solution for people in seeking the final clarity towards the marriage problems. This figure is consistent with the current trend worldwide upon this topic of single mothers. An enormous increase in the number of single mothers due to divorce has become a reasonable approach for the people in seeking the final clarity towards the marriage problems. In Malaysia, single mothers can be classified as in two variables which are parental death and spousal separation or divorce; parenting is a tough job without a spouse helping in a child's development. The aim of this study are to identify challenges face by single mother in Malaysia, policies on entrepreneurship, entrepreneurship activities and in Malaysia and survivability. This study apply qualitative method in describing challenges amongst single mother and policies on entrepreneurship by using data obtained from Department of Women Development in 2017 and previous studies. The results of the study show by developing policies and programs for single mothers, it could help them to survive for long period of time. This study contributes to the development of action plan in aiding single mothers in Malaysia to work and support single mothers from poverty.
\end{abstract}

Keywords: single mother, Malaysia, poverty, entrepreneurship, empowerment

\section{Introduction}

A woman who became a head of household and marriage status, widowed or divorced, stays with unmarried children in the same household as specified by the Ministry for Women Family and Community Development (KPWKM, 2015:2020). The second description is that of a single mother who leads the household and has an unhealthy husband, and has unmarried children. The third meaning is a female householder who is never married but has an adopted or unjustified child. As single mothers, their families have more responsibilities and struggles than partners. They must perform their own duties to raise and educate children and respond to the family's needs (Siti Marziah, Nurul Shafini, Noremy, Suzana and Jamiah, 2019; Faizah and Hazirah, 2013; Zanalisa, 2012 and Zakaria et al., 2020). They also have to fulfill their duty towards the family as a single mother. 
If the duties are not administered, they would be in dispute. Therefore, they have to learn the techniques of coping with conflicts in life. Lazarus (1984) describes individuals' ability to handle unbalanced external and internal demands resulting in burden as an individual conduct to alter thinking or behavior. However, united mothers find it easy to feel depressed if they fail to satisfy internal and external demands. Studies by Siti Ruhani (2016) and Wan Ibrahim (2006), for example, have shown that single mums receive much physical assistance, for example, financial support and empowerment. Physical support will only help them meet external requirements. Yet psychological problems like depression will still be experienced (Siti Marziah, Noremy and Faradillah, 2018, Zainab, 2014). Internal elements, such as techniques for managing pressures and other associated internal issues, can also be extended to single moms. The number of weddings increased by $1.2 \%$ from 203,741 (2017) to 206,253, as shown in Table 1. (2018). The gross marriage rate (CMR) was, however, only 6.4 per thousand inhabitants. In 2018 there were 150098 Muslim marriages, an increase of 1.9 percent from 147 282. (2017). CMR rose by 1,000 Muslims from 7.5 (2017) to 7.6 (2018). Non-Muslim weddings decreased from 56.459 (2017) to 56.155 by 0,5 percent (2018). The non-Muslim population in CMR remained at 4.5 per 1,000 .

Table 1: Number of marriage and crude marriage rate (CMR), Malaysia, 2017 and 2018

Source: Department of Statistics Malaysia (2019)

\begin{tabular}{lllllll}
\hline Year & \multicolumn{2}{l}{ Number of marriages } & \multicolumn{3}{l}{ Rate (Per1,000 population) } \\
\cline { 2 - 7 } 2017 & Malaysia & Muslim & Non-Muslim & Malaysia & Muslim & Non-Muslim \\
2018 & 203,741 & 147,282 & 56,459 & 6,4 & 7,5 & 4,5 \\
\hline
\end{tabular}

As shown in Table 2, from 50,314 (2017) to 50,345 divorces rose by $0.1 \%$. (2018). The gross divorce rate (CDR) stood at 1,6 per 1,000. In 2018 there have been 40269 Muslim divorces, up 1.4 percent from 39709-Muslim divorces (2017). The CDR stayed at 2.0 per 1,000 Muslims. Non-Muslim divorces were decreased by 4.9 percent to 10,087 from 10,605 (2017) (2018). Consequently, Non-Muslim CDR marginally increased from 0.9 (2017) to 0.8. (2018).

Table 2: Number of divorces and crude divorce rate (CDR), Malaysia, 2017 and 2018 Source: Department of Statistics Malaysia (2019)

\begin{tabular}{lllllll}
\hline Year & \multicolumn{2}{l}{ Number of divorces } & \multicolumn{3}{l}{ Rate (Per1,000 population) } \\
\cline { 2 - 6 } & Malaysia & Muslim & Non-Muslim & Malaysia & Muslim & Non-Muslim \\
2017 & 50,314 & 39,709 & 10,606 & 1,6 & 2,0 & 0,9 \\
2018 & 50,356 & 40,269 & 10,087 & 1,6 & 2,0 & 0,8 \\
\hline
\end{tabular}

Single mothers and even households headed by women face life problems, which is in line with the 11th Malaysia Plan (2016-2020) to bring well-being and stability to Malaysians. Sabah, in particular, has demonstrated the highest household poverty rates in Malaysia, and the growing number of mothers has contributed indirectly to the increase. The single mothers in Sabah may have household poverty, which may lead them to open up companies to generate income for their households.

Studies show that there are rising cases of the discontinuation of these single mother businesses (Roddin, Sidi, Yusof, Mohamed \& Abdul Razzaq, 2011). Many of them have engaged with various companies, but with only minimal experience and poor entrepreneurship skills, with established support schemes. Some may have low earnings, and intermediaries that provide their business operations with goods exploit them (Roddin et al., 2011). Therefore, their limited knowledge, lack of institutional support and competence are the most important reasons for difficulties facing the single mom entrepreneurs (Ali, Som, Bujang \& Abu Bakar, 2004).

Table 3: Number of Single Mother in Malaysia

Source: Department of Women Development (2017)

\begin{tabular}{lllllll}
\hline Age & Malay & Chinese & Indian & Sabahan & Sarawakian & Others \\
& & & & & \\
\hline $20-24$ & 14 & 3 & 0 & 0 & 1 & 0 \\
& & & & &
\end{tabular}




\begin{tabular}{lllllll}
\hline $25-29$ & 36 & 8 & 2 & 2 & 2 & 1 \\
$30-34$ & 61 & 14 & 10 & 3 & 4 & 0 \\
$35-39$ & 55 & 7 & 8 & 1 & 1 & 0 \\
$40-44$ & 64 & 7 & 0 & 0 & 0 & 0 \\
$45-49$ & 69 & 7 & 5 & 1 & 0 & 0 \\
$50-54$ & 70 & 1 & 2 & 0 & 1 & 1 \\
$55-59$ & 71 & 2 & 2 & 1 & 0 & 0 \\
$60-64$ & 69 & 1 & 3 & 1 & 0 & 0 \\
$65-69$ & 58 & 0 & 0 & 0 & 0 & 0 \\
$70-74$ & 39 & 0 & 1 & 0 & 0 & 0 \\
$75-79$ & 43 & 1 & 0 & 0 & 0 & 0 \\
$80-84$ & 22 & 0 & 0 & 0 & 0 & 0 \\
$85-89$ & 3 & 0 & 0 & 0 & 0 & 0 \\
\hline $89+$ & 8 & 0 & 0 & 1 & 1 & 0 \\
\hline
\end{tabular}

Some of them could not even continue their business after starting the business, because they have lost confidence and motivation. The household poverty as an example may therefore have driven the individual mothers to start a business and affect their entrepreneurial success. However, what is the positive reasons for the entrepreneurial success of the single mother? Nothing is known of the motives of single mother entrepreneurs who affect their business's survival, despite the broad-based research of single mothers in Sabah.

Furthermore, with digital progress, the use of social media is useful for business success (Vlachvei \& Notta, 2015). To gain a competitive advantage over rivals to survive, the creation of social media strategies would boostthe business results (Wu, 2015). Nonetheless, how do single mothers use social media and how their use of socialmedia affects their business success? Single mother entrepreneurs have conducted limited research on social media use, and how it affects their growth. This concept paper aims to explore the relationship among single mother entrepreneurs between entrepreneurial inspiration, social media use, and entrepreneurial success.

\section{Method}

This study employed data obtained from Department of Statistics Malaysia and Department of Women Development from 2017 to 2019 for qualitative methods which scrutinized on the numbers of divorces, numbers of marriage and numbers of single mothers in Malaysia. By using these data, this study explained on the challenges which faced by single mothers and policies developed by the government in aiding them through hard time. On top of that, this research apply descriptive approach which enables researchers to explain the phenomena from the data regarding single mother in Malaysia also previous studies to explain on challenges, policies, entrepreneurship and survivability.

\section{Discussion}

\subsection{Single Mothers Challenges}

Single moms have been part of the culture for a long time, but women and families have been addressed only a bit. The group is used to debating single mothers rather than single parents (Choi, 2010; Choi \& Jackson, 2011; Doherty \& Craft, 2011). A single mother's status poses a significant challenge for these women to continue a life they never expected. Mothers face many conflicts in their everyday lives, including stigma, culture, conflicts about themselves or their positions, problems for their children and their families. Single mothers generally become more responsible than single fathers after divorce or breakup that they once shared with their husbands. This leads individual moms indirectly to double roles and can trigger more pressure (Siti Rafiah \& Sakinah 2013, Zakaria et al,. 2019). Mothers manage their families and juggle the finances of their families and control the growth, education, and place of their children (Zaini, 2014). Problems occur when they have to raise them on their own if a parent is left to children for divorce. Their status and family structure have changed and will change their family roles (Nichols, 2010).

In the emotional adaptation process, as described by Cairney\&Wade (2002) and Wade\&Cairney (2000), emotional, physical and spiritual support is surely required for individual mothers. Previous studies indicate that divorced mothers are under more strain than married mothers due to a lack of physical and emotional support (Cooper, McLanahan, 
Meadows, \& Brooks-Gunn, 2009, Fenner \& Zakaria., 2019). Person mothers usually have greater stress than married mothers (Cairney, Boyle, Offord, dan Racine, 2003). Who is a single mother, which has led many scientists to understand this group? (Mohd Ismail, Robiah, Syarifah, Kamarul Azmi, \& Ahmad Kilani, 2006; Najwa, 2005; Rozumah, Krauss, Baharudin,Siti Nor \& Pei, 2011; Zabkiewicz, 2010; Zaini, 2014; Siti Rafiah \& Sakinah 2013; Dharatun Nisa 2017; Williams 2016; Thahira Bibi et al. , 2016). There are several different categories of single mothers based on the Single Mothers National Plan 2015-2020 (2015), women who are the heads of a household, have married or divorced or have fully separated themselves and have children with unmarried status in the same household and ii) women who are heads of the household and have the husband (her husband is uncomfortable and unable to work) and have chil unmarried (adopted or illegitimate child).

The management techniques employed by single mothers differ depending on how they live. McKendrick, Campbell, and Hesketh (2018) found that there are three most common policies that individual mothers use to embrace, prepare, and cope with their destiny. A research carried out in Scotland also found that single mothers are more selfsufficient than others seeking assistance and advice. Single mothers are also looking for social assistance to address job tension. However, social support between single mothers and partnering mothers varies greatly. Zakaria et al. (2020b) considered married mothers to be more socially supported than single mothers since they have partners who share and talk about friendly matters concerning their current problems. Napora, Andruszkiewicz and Basinska (2018) stated this. The technique refers to how an individual's thinking and action are used to deal with stressful situations (Lazarus \& Folkman, 1984).

The coping strategy is viewed as a particular action that helps to improve a person by Salhah, Sapora, Dini, and Rezki (2011). Often optimistic feelings contribute to coping strategy. The person produces these positive emotions himself (Philippe, Lecours, \& Bealieu-Pelletier, 2009). Previous research showed that when faced with pressures, resilience, strategy, and positive emotion are different (Ong \& Zautra, 2010). Taylor (2014) indicates that coping mechanisms are regarded as an individual mechanism that needs adaptation and pressure management. Resilience means complex systems' ability to respond fully to disruptions that endanger the functioning or growth of the system (Masten, 2014). From a psychological perspective, resilience includes the behavior, thinking, and actions which a person may learn and improve. The resilience is correlated with the enhanced efficiency and satisfaction of a trade, according to Avey, Reichard, Luthans, and Mhatre (2011).

In the meantime, Mansfield, Beltman, Price, and McConney (2012); Miller and Chen (2017) found that resilience can secure people against stress and burnout. S. Gulfem Cakira (2010) and Mad Kassim (2011) have been faced with high stress by single mothers due to their duties. Wolf (2011); They face emotional and psychological conflicts because of the obstacles they face. Avoiding actions indicates a good deal of tension. Single mothers prevent and refrain from dealing with the situation they face that affects their psychological aspects and raises their stress. The findings have shown a positive link to stress for social support behavior. Many parties, mainly family and friends, may give rise to excessive social support thatcaused single mothers' stress. The respondents were mostly between 50 and 60 years old in this sample. They mayhave been stable and had absolutely no need for social support. With their lives, they have no problem. The findings showed no association to stress with the emotion-centered actions of the sample. This is probably because the samplingaging factor in this research was between the ages of 50 and 60 , and the emotions have normalized because they spend a relatively long period alone. The environmental factors did not distract them easily.

\subsection{New Economic Policies on Entrepreneurship}

Rosli Mahmod et al. (2013) indicated that the entrepreneur is an individual who carries out a business with the aim of profit and strategically effective practices. The contractor is someone who maximizes opportunities, according to Peter Drucker (1964); a contractor is a manager of a business. The focus of this study is on single mothers engaged in business activities. Therefore, single mothers' income is split into corporate income and non-commercial revenue in this report. Company revenue is revenue derived from enterprise operations, while non-business revenue is income derived from activities other than business. Next, transfer payments, such as pensions, scholarships, and zakat, are income without any productive work. Poverty alleviation is the main sustainable development priority in most developed nations worldwide (Siwar, Ahmed, Bashawir, \& Mia, 2016). The United Nations, for example, has begun dealing with the problem of poverty, and since 1988 the Millennium Declaration was created. One of Millennium's goals (MDG) is to minimize poverty and malnutrition (Samat, Elhadary, Hijles, Ghazali, \& Sirat, 2012). 
This is how poverty is viewed, a mixture of different factors that's more than just a case of income loss and not just a one-facetted phenomenon. The word refers to the various adverse effects of society, psychology, and the environment: domestic violence, crime, insufficient perceived social expenditure, and the issues of human capital growth, unequal service provision and low political involvement. Poverty is therefore specified by country (Hatta \& Ali, 2013). Individuals living in this poverty at less than $\$ 2$ a day for developing economies are now considered the world's and world's median poorest (Bruton, Ketchen, \& Ireland, 2013). The poor problem with a small proportion of its people has existed in Malaysia for a very long time. Like other developing countries, Malaysia has taken a long time through the idea of micro-entrepreneurship to introduce poverty reduction policies. The objective was to lead in 1970 to socio-economic transition through the new economic policies (Halim, Zakaria, Hamid, \& Khalid, 2017).

Malaysia has undergone a long process of economic, social, and political reforms over the last decades to increase Malaysian socio-economic well-being, boost entrepreneurial literacy, and contend with poverty at all levels of society. The Malaysian administration recognizes entrepreneurship as a fundamental building block of national economies, contributing substantially to job growth and poverty reduction (Halim et al., 2017). Entrepreneurial activity, a key to economic growth and development, fosters prosperity through new jobs, unemployment alleviation, and improved economic growth and regional development (Kareem, 2015). Malaysia's social and economic policy has recently contributed to the elimination of poverty through micro-enterprise programs. Various challenges in Malaysia have marked the market climate of new contractors, micro and small enterprises. The main obstacles are high external regulation, weak financial management, lack of skills and entrepreneurship, and lack of energy against formidable rivals. Their challenges are also high.

Therefore, the business concept practice is essential in developing microentrepreneurs in information growth, skill development and entrepreneurial features (Halim et al., 2017). Entrepreneurship growth contributes to poverty by generating jobs through the launching of new entrepreneurship to expand existing ones. Furthermore, new employment, new institutional types, new technology, new industry, markets, net productivity increases, and income increases, which peak at higher living standards for people growing social wealth. Social prosperity is increasing. Therefore the poverty indicators will decline as the number of entrepreneurs in those countries increases (Ali \& Ali, 2013). Apart from developing countries, the companies that help mitigate poverty in the least developed countries are essential for scholars, managers, and policymakers (LDCs). It plays a vital role in alleviating poverty because it sells to people from poor countries, hires them, or can be made up of them, as shown by the UN Millennium Development Goals (Maksimov, Wang, \& Luo, 2017).

As it seems to be generally regarded as an economic growth driver, the interest in entrepreneurial economy is the interests of governments across the globe. Malaysia's government plays a vital role in poverty eradication by encouraging income-generation initiatives, providing facilities for improving quality of life, and running programsto promote the poor's positive values. Several governmental corporations, such as the Federal Land Development Authority, the Small Holders Developing Authority of the Rubber Industry (RISDA), and the Federal Land Consolidation and Rehabilitation Agency, have been established to enact these policies to address poverty (FELCRA). These businesses establish special schemes and programs to eradicate poverty (Halim et al., 2017). In Malaysia, social entrepreneurial practice in NEP creates better lives for human beings, business education, industrial expansion and employment (Halim et al., 2017). In Malaysia, the social entrepreneurship activity in NEP develops better human lives, entrepreneurship, industrial growth and employment opportunities (Halim et al., 2017). Social entrepreneurship has recently drawn researchers' attention (Ahmad, Najafizada, \& Cohen, 2017). It can build trust in choice through acknowledgment of social entrepreneurship and among social entrepreneurship. Universities should teach the definition of social entrepreneurship to help students to create a more successful sales tactic, particularly for the lower-income community, as a topic within their management course (Zainol, Daud, Abdullah, \& Yaacob, 2014). Besides, one of the NEP's functions is to deal primarily with income imbalances among ethnic groups, income groups, economic sectors, regions, and countries (Halim et al., 2017).

\subsection{Single Mother Entrepreneurship}

Malaysia is an emerging nation with a projected stable economic growth rate of $4.5 \%$ to $5.0 \%$ in 2015. (BNM, 2014). In addition, out of 61 nations, Malaysia is the 14th most competitive country globally (IMD, 2015). However, its achievements are mostly seen from a macroeconomic point of view, reflecting the economy as a whole about the 
microeconomic side that examines small units, like households, which eventually affect a nation. Thefocus of this study is the single mothers' group. Single mothers are generally seen as women who haveno husband or who can be divorced or widowed. The concept of a single mom should, however, satisfy three criteria:women who are divorced and who have children, women who still have dependent children, and women who must care for their family after the husband has been afflicted with critical disease, and unmarried women.

Siti Fatimah (2015) noted that single moms are women responsible for performing a dual role both as a woman and as the head of a family, both alone and without a spouse. Gucciardi, Celasun \& Stewart (2004) also claimed that single moms are unmarried women who no longer live with their ex-husband or widowho are still living with their children on the same roof. Since they must help and educate their children alone, they most certainly have a income source to survive. Some people can work in the private or government sectors, and some people do business. Besides this income stream, they may also obtain income from transfer payment sources such as pensions, Zakat funding, social security assistance, and child transfers.

A wife who relies on her husband to provide her entire family's security and necessities will definitely experiencethe difficulties, mainly when they are separated or after their husband's death. The condition would become worse if they never participated in income-generating activities. But if some of them have revenue in the form of transferral payments such as their husband's pensions, or probably the assistance from the department that runs zakas, insurance companies etc. However, her husband's absence or death could not impact the woman who has a career and a stable income before becoming a single parent. Many of these single mothers are prepared to undertake multiple dire situations to help their children survive.

With the economic situation more accessible today, they believe that engaging in business practices or entrepreneurial activities is a convenient way to obtain financial capital. Many training programs have been introduced to improve and increase their income, especially on women's skills and entrepreneurship. With a grant of RM10 million in 1998, a Women Entrepreneurs Fund was established to enhance women's participation in the industry. A total of 12 RM9.5 million projects under this fund have been funded. A total of 6,000 contractors have secured loans of RM65 million from the Small Entrepreneur Fund (RMK-7, 1996-2000). The issue of empowerment of single mothers also continuesto get government attention, and it is one part of the Eighth Malaysia Initiative to promote the participation of 22,850women in entrepreneurship through Amanah Ikhtiar Malaysia (AIM) with micro meditation facilities. This initiative also includes many government training programs to help individual mothers find jobs. Appropriation (RMK-8, 2001-2005).

Sixty-seven thousand women from the small-income community participated in micro-based loan companies under Plan9 in Malaysia, under the Ikhtiar loans system implemented by Amanah Ikhtiar Malaysia (AIM). 2.800 individual moms participated in the particular single-mother scheme developed by AIM in 2001. (Source: RMK-9, 2006-2010). When drafting the national economic plan, government problems relating to women and single mothers are never overlooked.Supported by the fact that over 147,000 women have been active in the Nur Bestari Leadership Programme, over 23,000 women in the Jejari Bestari Entrepreneurship Programme, and 750 individual mothers in the Entrepreneurial Skills I-KIT. (RMK-10, 2011-2015 Source. While various financial and machinery support facilities are given through public policy and NGOs, the number of single-mother household heads in Kedah is at 10.7 percentamong the highest, equal to the rate of the state of Terengganu. Their number is also 10.7 percent. In the meantime, Kelantan reported as head of the household the highest (12.4 percent) single mothers in poverty.

\subsection{Survivability of Single Mother}

The Kotwal and Bharti (2009) study show that $88 \%$ of the family reasons come from women with single parents, and $6 \%$ from separation and divorce. A single mother's survival can be defined as widowed or divorced women who are not married and live in the same households and are the primary caregivers. ii) women who are significant family breadwinners but the husband cannot work because of the awful disease. Children who arenot married and live in the same homes (iii) single women who are the principal suppliers receive custody or are out of wedlock from someone else's children (Noor Watee et al., 2017).

As Montgomery County (2009) said during their studies, handling the husband-free family is one of the difficulties most single mothers have to face, but not all single mothers feel that this is a kind of challenge. Moreover, as other 
researchers have noted, most women or mothers think that one of the most satisfying functions no woman accepts is (Edwards \& Duncan, 1996). Montgomery County (2009) added that an organization's problems, which appear tobe one of the causes of poverty, are also linked to their obligations. Being a single mother with difficulty caring for children after breaking up with husband was not on her mind and, even worse, the husband cannot give the family the burden because he omits stealing the wife's asset, such as a car (Biggs, 2005). Moreover, as some other investigators have said,most women or mothers believe that one of them plays the most crucial part any woman has not accepted (Rosalind,2014).

Sussman and Hanson (2014) said that poverty is a crucial issue for single mothers to see whether or not these are meaningful obstacles. This is because single mothers have financial problems contributing to poverty (Kotwal \& Bharti, 2009). Besides, as Ruggeri and Bird (2014) have studied, single mothers must also survive to take a seat in a company that means that they have many obstacles to participate or participate in the workforce and this has something to do with full employment. They continue to say that employment problems may lead single mother to experience the impact or risks of living in poverty with younger dependent children (Ruggeri \& Bird, 2014).

Kotwal \& Bharti (2009) have already studied that single mothers have problems coping with their emotional or mental depression. Another researcher said the same as he found that several of their individual parents were under stress (Mitstifer, 2008). Further research by previous scientists has shown that different social stresses contributeto the stress of single mother. Otherwise, single mom will often get sick, cause additional pressure, and then the mother's actions towards her children will be influenced by the juggling responsibility she has to face (Mitstifer, 2008). Some researchers suggest in response that the public and private sectors should help the survival of single mothers sothat they resolve barriers since those barriers can have significant implications for a single mother's entire life (Emma et al., 2015). There are also different perceptions for single mothers, which Nelsen et al. may describe as myth (2012).

The misconception is that children live among single parents without a stable relationship with each other. That single mother is believed to be insufficient to become a role model for children. Nelsen et al. (2012) have, however, found such perceptions not accurate, since 43 percent of single-parent children were happy to live, and the proportion of children who live in ideal families was almost the same. They also said that a single mother can still play a role model without a partner, for a single mother knows everything about how to grow her family through her family's parenting classes.

\subsection{Empowering Single Mothers in Malaysia}

For single mothers in all parts of the world, life can be a struggle, particularly for those living in poverty. In Malaysia, single mothers primarily suffer from spousal death, abandonment, or divorce. Many face financial difficulties and the majority of rural single moms also lack the skills needed to get a proper job and education. Many of these single mothers have little choice but to embrace poorly paying, low-level employment is generally unfavorable working conditions, and unluckily few use sex trafficking to meet these barriers. Unofficial statistics showed that single moms in Malaysia have five or more children on average in rural areas. Even more single mothers are homeless and forced to use modest government aid to provide food even though they cannot offer their children and saddled up with the added responsibility of caring for extended family members. Mothers strive to gain financial freedom, and those women hardly have savings or very little savings on their own. They were entirely reliant on finances for their husbands. When they are single mothers, the responsibility of fighting for survival is placed on their shoulders. These single mothers of 40 and older years found it a great challenge to join the formal workforce because most had never worked before because they were married at a very young age. They appear to be slightly lost and do not know how to get a job, particularly if the experience, skills, and training needed to make them workable were missing. One development of the Ninth Plan for Malaysia (2006 2010 ) is the need to resolve persistent socio-economic inequality to eliminate poverty, reducing differences in income, jobs and wealth. In this context, the plight of single mothers and women's households was a concern for the government a long time ago, especially as trends indicate that households in rural areas increasingly feminize poverty. For Government support, UNDP Malaysia carried out, in 2008, extensive research into the plight of single mothers in Malaysia, particularly those classified as poor and poor, in their partnership with the Ministry for Women, Family and Community Development. The long-term aim of the Millennium Development goal 1 to Eradicate poverty was to ensure the requisite institutional support and political attention for empowering and getting single mothers out of poverty. 


\subsection{Strengthening policies and program for single mothers}

The UNDP supports the country-wide survey and works at the grassroots level to allow the project to understand and insight into the plight of single children directly involved with the local single mother's organizations, leaders, and single mothers themselves through comprehensive dialog sessions and interactions. During the national purpose study, dialog sessions showed that certain single mothers are doing many jobs to achieve familial ends. After the divorce proceedings had concluded, several divorced husbands would not care for child support. As a result, policies and services to support single mothers in childcare and child-care are essential to ensuring that they do not fall into the pit of poverty.

The project gained substantial knowledge with this rich knowledge and quality input to address issues relevant to the realities of single motherhood and was able to develop a draft National Action Plan with strong policies and programs which would efficiently empower individual moms by addressing underlying causes and by using the analysis of trends and patterns of single mothers. "There are many programs and policies throughout the country aimed at the vulnerable and needy. Cik Siti Altaf Deviyati, the Single Mothers Project Manager, however, reports that very few concrete programs and policies have been drafted to support mothers alone. "This initiative will pave the way for policy-making and services that will enable them to develop economically out of poverty."

Cik Siti Altaf said: "Single moms will certainly profit from custom-built policies and programs in areas such as appropriate childcare facilities when they choose to work, child education, training, and skills training to allow them to work, to name only a few (UNDP, 2018). We hope that the single mothers of Malaysia will be better motivated and better equipped by implementing the National Action Plan to face their many challenges more positively." The project team also received more focused feedback on surveys across the country. To establish a National Action Plan to empower single mothers in Malaysia and guarantee the institutional support, efficient policy, and services required to empower and raise single mothers out of poverty, the results of the survey and formal report were submitted to the government.

\subsection{Social media and entrepreneurship}

The use of social media has moved beyond management of personal relationships for entrepreneurs. Entrepreneurs today use it in building, expanding and improving networks (Ahmad et al., 2017) which is supported by its concepts (Mohajerani et al., 2015; Smith et al., 2017). This makes for networking and contact with individuals from a different geographical area with close or varied socioeconomic and demographic backgrounds (Wang et al., 2017). Fischer and Reuber (2014) stated that social networks allow for contact which improves differentiation of the business. Song (2015) found that entrepreneurs use diverse social media channels with an overlap (between 19-29 percent on multiple platforms) in their social network contacts which enables to them to have high network connectedness. In building partnerships, entrepreneurs accumulate good and weak bonds (Quinton \& Wilson, 2016). In other means, entrepreneur especially single mother entrepreneurs should use social media to achieve the strategic edge as part of their plan to succeed. There are various types of social media platforms which can offer benefits to single mother entrepreneurs. Nevertheless, how can social media be helpful for their market results to attract their customers? This may be demonstrated by the fact that social media offers ways for businesses to interact in a twoway conversation with their clients. Thus, social media is favorable to firms' success.

\section{Conclusion}

The study identified Malaysia's challenges, business activity, and empowerment for individual mothers. Based on the discussion, the study explored that single mother in Malaysia had gone through a lot during their hard time Society gives single mothers a bad view. A single mother, composed of the average family, is a person who cannot run a household perfectly. Divorced single mothers are marked as irresponsible women who have no good at taking care of their husbands because of single mothers' status. Their husbands have divorced them because of that, but society alsobelieves that individual mothers should be blamed when their husbands divorce them. It will never be successful as married women do everything that single mothers do. The stigma of society against single mothers has worsened from day to day, generating more problems for their position in society according to the stigma or perception of society towards single mothers. 


\section{Acknowledgments}

I would like to thank you to co-authors of this papers who have entrusted me to write on the particular title regarding single mothers in Malaysia as they also have contributed to the development of ideas for this paper. Secondly, I would like to thank to my friends who helped me a lot in finalizing this paper within the limited time frame.

\section{References}

Ahmad, S., Najafizada, M., \& Cohen, M. J. (2017), Social entrepreneurship tackling poverty in Bamyan Province, Afghanistan. World Development Perspectives, 5, 24-26.

Ali, A. Y. S., \& Ali, A. H. (2013), Entrepreneurship development and poverty reduction: Empirical survey from Somalia. American International Journal of Social Science, 2 (3), 108-113.

Ali, A.M., Som, H.M., Bujang, S.M., \& Abu Bakar, T.S. (2004). Aktiviti Keusahawanan di Kalangan Ibu Tunggal di Johor: Kajian terhadap Faktor Penglibatan dan Kejayaan dalam bidang perniagaan. Jurnal Kemanusiaan, 2 (2), 53-75.

Avey, J. B., Reichard, R. J., Luthans, F., \& Mhatre, K. H. (2011). Meta-analysis of the impact of positive psychological capital on employee attitudes, behaviors, and performance. Human Resource Development Quarterly, 22, $127-152$.

Baharudin, Rozumah; Krauss, Steven Eric; Yacoob, Siti Nor; Pei, Tan Jo. (2011) Family Processes as Predictors of Antisocial Behaviors among Adolescents from Urban, Single-Mother Malay Families in Malaysia. Journal of Comparative Family Studies, Volume 42 Issue 4, July-August, pp. 509-522

Bank Negara Malaysia. (2014), Prospek Dan Dasar Pada Tahun 2015. Dicapai dari http://www.bnm.gov.my/files/publication/ar/bm/2014/cp04.pdf

Biggs, N. E. (2005). The Single Mother's Journey to Wholeness: Hope and Help for Single Moms. iUniverse. Bruton, . D., Ketchen, D. J., \& Ireland, R. D. (2013), Entrepreneurship as a solution to poverty. Journal of Business Venturing, 28 (6), 1-7.

Cairney, J., \& Wade, T. J. (2002). Single parent mothers and mental health care service use. Social Psychiatry \& Psychiatric Epidemiology, 37 (5), 236.

Cairney, J., Boyle, M., Offord, D. R., \& Racine, Y. (2003). Stress, social support and depression in single and married mothers. Social psychiatry and psychiatric epidemiology, 38(8), 442-449.

Choi, J.-K. (2010). Nonresident Fathers' Parenting, Family Processes, and Children's Development in Urban, Poor, Single-Mother Families. Social Service Review, 84(4), 655-677.

Choi, J.-K., \& Jackson, A. P. (2011). Fathers' involvement and child behavior problems in poor African American single-mother families. Children \& Youth Services Review, 33(5), 698-704. DOI: 10.1016/j.childyouth.2010.11.013

Cooper, C.E., McLanahan, S., Meadows S.O., \& Brooks-Gunn, J. (2009). Family structure transitions and maternal parenting stress. Journal of Marriage and Family, 71(3), 558-574.

Department of Statistics Malaysia. (2019). Marriage and Divorce Statistics, Malaysia 2019. Retrieved fromhttps://www.dosm.gov.my/v1/index.php?r=column/cthemeByCat\&cat=453\&bul_id=d1BZVzBZYXV wOTBPdXhGVEJTQW14dz09\&menu_id=L0pheU43NWJwRWVSZklWdzQ4TlhUUT09

Dharatun Nissa binti Puad Mohd Kari (2017). Strategi Daya Tindak dalam Kalangan Ibu Tunggal Kematian Pasangan. Unpublished PhD Thesis. Fakulti Pendidikan Universiti Malaya Kuala Lumpur

Doherty, W. J., \& Craft, S. M. (2011). Single Mothers Raising Children with 'Male Positive' Attitudes. Family Process, 50 (1), 63-76. DOI: 10.1111/j.1545-5300.2010.01346.x

Drucker, P. F. (1964). The Effective Administrator. The bulletin of the National Association of Secondary School Principals, 48 (291), 157-166.

Edwards, R. \& Duncan, S. (1996). "Chapter 6: Rational economic man or lone mothers in context? The uptake of paid work" in Good Enough Mothering? Feminist perspectives on lone mothering, edited by Elizabeth Bortolaia Silva. London: Routledge.

Emma, G., Catherine, J. S. \& Mumtaz, M. K. (2015). Single-Parent Families in Singapore: Understanding the Challenges of Finances, Housing and Time Poverty. SMU Change Lab. Lien Centre for Social Innovation Reports.

Faizah Abd Ghani dan Hazirah Hashim. (2013). Challenges and Locus Control among Single Mothers in Muar, Johor. Journal of Emerging Trends in Educational Research and Policy Studies (JETERAPS). 4 (5):760-765. 
Fenner. P, Zakaria B Mohamad (2019). What We Have Shared is Actually A Big Secret: Group Arts Therapy with divorced Single Mothers in Malaysia. Journal of the American Arts Therapy Association. 1-9.

Fischer, E., \& Reuber, A. R. (2014). Online entrepreneurial communication: Mitigating uncertainty and increasing differentiation via Twitter. Journal of Business Venturing, 29(4), 565-583.

Gucciardi, E., Celasun, N., \& Stewart, D. E. (2004), Single-Mother Families In Canada. Canadian Journal of Public Health. Canada: Canada Public Health association

Halim, M. A. S. A., Zakaria, Z., Hamid, A. C., \& Khalid, M. K. A. (2017), Fostering micro-entrepreneurship as panacea to poverty eradication in the Malaysian economy: A conceptual perception. Asian Social Science, $10(13), 287-292$.

Hatta, Z. A., \& Ali, I. (2013), Poverty reduction policies in Malaysia: Trends, strategies and challenges. Asian Culture and History, 5(2), 48-56.

Institute for Management Development (IMD) (2015), World Talent Report 2015' GoinGlobal. www.goinglobal.com/articles/1635.

Kareem, R. (2015), impact of entrepreneurship on poverty alleviation. Journal of Business Administration and Education, 7(1), 1-16.

Kementerian Pembangunan Wanita, K. D. M. (2015). Pelan Tindakan Pemerkasaan Ibu Tunggal 2015-2020. In K. D.M. Kementerian Pembangunan Wanita (Ed.). Putrajaya

Kementerian Pembangunan Wanita, Keluarga Dan Masyarakat. (2014), Program-Program Pembangunan Kapsiti Untuk Wanita Yang Disediakan Oleh Jabatan Pembangunan Wanita. Dicapai dari $h t t p: / / w w w$. kpwkm.gov.my/documents/10156/e85f39cc-flad-4d08-b7db-46011bf6036a

Kosmo Online. (2015, Jun 16), Definisi Baru Ibu Tunggal oleh Datuk Seri Rohani Abdul Karim. Dicapai dari http://www.kosmo.com.my/kosmo/content.asp?

Kotwal, P. \& Bharti, N. (2009). Problems Faced by Single Mothers. Journal of Social Science, 21 (3), 197-204.

KPWKM (2015). Pelan Tindakan Pemerkasaan Ibu Tunggal 2015-2020. Diakses

daripada

https://www.kpwkm.gov.my/kpwkm/uploads/files/Dokumen/BUKU\%20PELAN\%20TINDAKAN\%20PE

MERKASAAN\%20IBU\%20TUNGGAL.pdf

Lazarus, R. S. \& Folkman, S. (1984). Stress, appraisal and coping. NY: Springer Publishing.

Mad Kassim (2011) Stres, kecelaruan mental dan strategi daya tindak dalam kalangan ibu Tunggal etnik Bajau Sabah. Unpublished PhD Thesis. Universiti Malaysia Sabah.

Mahmood, R., \& Rosli, M. M. (2013). Microcredit position in micro and small enterprise performance: the Malaysian case. Management research review.

Maksimov, V., Wang, S. L., \& Luo, Y. (2017), Reducing poverty in the least developed countries: The role of small and medium enterprises. Journal of World Business, 52(2), 244-257.

Mansfield, C. F., Beltman, S., Price, A., \& McConney, A. (2012). Don't sweat the small stuff: Understanding teacher Resilience at the chalkface. Teaching and Teacher Education, 28(3), 357-367, http://dx.doi.org/10.1016/j.tate.2011.11.001

Masten, A. S. (2014). Ordinary magic: Resilience in Development. New York, NY: Guilford

McKendrick, JH, Campbell, L-A. and Hesketh, W. (2018) Coping strategies: how do single parents in Scotland cope with problems? OPFS/SPIRU Briefing 2018/3. Edinburgh: OPFS.

Miller, G. E., Chen, E., \& Zhou, E. S. (2007). If it goes up, must it come down? Chronic stress and hypothalamicpituitary-adrenocortical axis in humans. Psychological Bulletin, 133 (1), 25-45. DOI: 10.1037/00332909.133.1.25

Mitstifer, D. I. (2008). The Stress of Single Mothers and Its Effect on Quality Child Care. Undergraduate Research Journal for the Human Sciences, 7. Retrieved June 7, 2016, from http://www.kon.org/urc/v7/bronnimann.html.

Mohajerani, A., Baptista, J., \& Nandhakumar, J. (2015). Exploring the role of social media in importing logics across social contexts: The case of IT SMEs in Iran. Technological Forecasting and Social Change, 95, 1631.

Mohd Ismail, M., Robiah, Y. a., Syarifah, C., Kamarul Azmi, J., \& Ahmad Kilani, M. (2006). Permasalahan ibu tunggal dalam melaksanakan tanggungjawab pendidikan anak-anak: Satu kajian di kawasan Sura, Dungun, Terengganu Darul Iman. In A. R. Abd Rahim, H. Sufean, \& H. Che Hashim (Eds.), Krisis dan konflik institusi keluarga. Kuala Lumpur: Utusan Publications \& Distributors Sdn. Bhd. Siri Pembangunan Keluarga Utusan.

Montgomery County (Md.). (2009). Single mothers and poverty: agenda for action: education, employment, child 
care, income supports, health care, and housing. Montgomery County Commission for Women.

Najwa, M. S. (2005). Perkhidmatan pusat khidmat wanita di Sekretariat Pintas Negara terhadap ibu tunggal. Satu kajian dari perspektif Islam. Unpublished Master Thesis. Universiti Kebangsaan Malaysia.

Napora, E., Andruszkiewicz, A., dan Basinska, M.A. (2018). Types of Work-Related Behavior and Experiences and Stress Coping Strategies among Single Mothers and Mothers in Relationships Differentiating Role of Work Satisfaction. International Journal of Occupational Medicine and Environmental Health. 31(1):55-69.

Nelsen, J., Ed, D., Erwin, C. \& Delzer, C. (2012). Positive Discipline for Single Parents Revised and Updated 2nd Edition: Nurturing Cooperation, Respect, and Joy in Your Single-Parent Family. Three Rivers Press New York.

Nichols, M. P. (2010). Family Therapy Concepts and Methods (9th ed.). Boston: Pearson Education.

Noor Watee, R., Haslinda, A., Norazlina, D. and Amiraa, A. M. (2017). Key Challenges Contributing to the Survival of Single Mothers. J. Appl. Environ. Biol. Sci., 7 (4), 105-109.

Ong, A. D., \& Zautra, A. J. (2010). Psychological Resilience Predicts Decreases in Pain Catastrophizing Through Positive Emotions. Psychology and Aging, 25 (3), 516- 523

Philippe, F. L., Lecours, S., \& Bealieu-Pelletier, G. (2009). Resilience and positive emotions: Examining the role of emotional memories. Journal of Personality, 77 (1), 140-176.

Quinton, S., \& Wilson, D. (2016). Tensions and ties in social media networks: Towards a model of understanding business relationship development and business performance enhancement through the use of LinkedIn. Industrial Marketing Management, 54, 15-24.

Rancangan Malaysia Kelapan (RMK-8) (2001-2005), Unit Perancangan Ekonomi Malaysia. Dicapai dari http://www.epu.gov.my/eighth-malaysia-plan-2001-2005.

Rancangan Malaysia Kesembilan (RMK-9) (2006-2010), Unit Perancangan Ekonomi Malaysia. Dicapai dari http://www.epu.gov.my/epu-theme/rm9/bahasa/Bab13.pdf

Rancangan Malaysia Kesepuluh (RMK-10) (2011-2015), Unit Perancangan Ekonomi Malaysia. Dicapai dari http://www.epu.gov.my/epu-theme/ rm9/ bahasa/ Babl3.pdf

Rancangan Malaysia ketujuh (RMK-7) (1996-2000), Unit Perancangan Ekonomi Malaysia. Dicapai dari http://www.epu.gov.my/seventh-malaysia-plan-1996-2000.

Roddin, R., Sidi, N.S. S., Yusof, Y. Mohamed, M., \& Abdul Razzaq, A.R. (2011). Poverty alleviation among single mother in Malaysia: Building entrepreneurship capacity. International Journal of Business and Social Science, 2 (17), 92-99.

Rosalind, E. (2014). Why it is important to retain 'family' as a sociological concept. The Sociology Teacher, 3 (3), $18-21$.

Ruggeri, K. \& Bird, C. E. (2014). Single Parents and Employment in Europe. European Commission. 26

S. Gulfem Cakir. (2010) A pilot study on stress and support sources of single mothers in Turkey. Procedia Social and Behavioral Sciences 5, 1079-1083

Salhah, A., Sapora, S., Dini Farhana, B., \& Rezki Perdani, S. (2011). Strategi Daya Tindak Versi Bahasa Melayu. Paper presented at the PERKAMA International Counseling Convention.

Samat, N., Elhadary, Y. A. E., Hijles, F. M., Ghazali, S., \& Sirat, M. (2012), Poverty and deprivation: Using geographic information system. Journal of Social Sciences \& Humanities, 7 (2), 328-342.

Siti Fatimah, A. R. (2015), Ibu Tunggal: Semua Pihak Perlu Lebih Bertanggungjawab. Institut Kefahahaman Islam Malaysia. Dicapai dari http://www.ikim.gov.my /index.php/ms/artikel/7118-ibu-tunggal-semua-pihak perlulebihbertanggungjawab

Siti Marziah Zakaria, Noremy Md Akhir \& Faradillah Iqmar Omar. (2018). Kesejahteraan Psikologi Ibu Tunggal: Cabaran Sebagai Ibu Tunggal dan Tekanan Hidup. E-Prosiding Persidangan Antarabangsa Sains Sosial dan Kemanusiaan 2018. Kolej Universiti Islam Antarabangsa Selangor.

Siti Marziah Zakaria, Nurul Shafini Shafurdin, Noremy Md. Akhir, Suzana Mohd Hoesnit dan Jamiah Manap. (2019). Cabaran Hidup Ibu Tunggal: Kesan Terhadap Kesejahteraan Emosi. International Journal of Education, Psychology and Counseling. 4 (2):69-84.

Siti Rafiah, A. H., \& Sakinah, S. (2013). Exploring single parenting process in Malaysia: Issues and coping strategies. Procedia Social and Behavioral Sciences, 84, 1154-1159.

Siti Rafiah, A. H., \& Sakinah, S. (2013). Exploring single parenting process in Malaysia: Issues and coping strategies. Procedia Social and Behavioral Sciences, 84, 1154-1159.

Siti Ruhani Mohd Yusoff. (2016). Peranan Sikap, Pengetahuan dan Amalan Kewangan terhadap Pemerkasaan Ekonomi Ibu Tunggal. Tesis Master yang tidak diterbitkan. Pusat Pengajian Pengurusan, Universiti Sains 
Malaysia.

Siwar, C., Ahmed, F., Bashawir, A., \& Mia, M. S. (2016), Urbanization and urban poverty in Malaysia: Consequences and vulnerability. Journal of Applied Sciences, 16(4), 154-160.

Smith, C., Smith, J. B., \& Shaw, E. (2017). Embracing digital networks: Entrepreneurs' social capital online. Journal of Business Venturing, 32(1), 18-34.

Sussman, M. B. \& Hanson, S. (2014). Single Parent Families: Diversity, Myths and Realities. Routledge.

Taylor, Z. E., \& Conger, R. D. (2014). Risk and resilience processes in single-mother families: An Interactionist perspective. In Z. Sloboda \& H., Petras (Eds). Defining prevention science (195-217). New York, NY: Springer. doi:10.1007/978-1-4899-7424-2

UNDP. (2010). Empowering single mothers in Malaysia. Retrieved June 3, 2016, from http://www.undp.org/content/undp/en/home/presscenter/articles/2010/05/07/empowering-single-mothersin-malaysia.html

United Nations Development Programme (UNDP). (2018). Empowering Single Mothers in Malaysia. Retrieved fromhttps://www.my.undp.org/content/malaysia/en/home/courwork/ women empowerment/successstories/EmpoweringSingleMothers.html

Vlachvei, A., \& Notta, O. (2015). Understanding Social Media ROI in SMEs. International Organization for Research and Development - IORD.

Wan Ibrahim Wan Ahmad. (2006). Fenomena Ibu Tunggal dan Masa Depan Warga Tua Desa di Malaysia. Jurnal Pembangunan Sosial. 2006(9):85-108.

Wang, F., Mack, E. A., \& Maciewjewski, R. (2017). Analyzing entrepreneurial social networks with big data. Annals of the American Association of Geographers, 107(1), 130-150.

Williams, G. (2013). The Best Budgeting Strategies for Single Parents. Retrieved from: $\quad$ http://money.usnews.com/money/personal-finance/articles/2013/10/17/the-bestbudgetingstrategies-for- single-parents.

Wolf, J. Single Parent Statistics (2011) - Figures on Kids Being Raised By One Adult. Single Parents | Child Support and Child Custody | Help for Single Moms and Dads. United States Census Department, 26 Feb. 2010. Web.2 Dec. 2011.

$\mathrm{Wu}, \mathrm{C}$. W. (2016). The performance impact of social media in the chain store industry. Journal of Business Research. 69(11), 5310-5316.

Zabkiewicz, D. (2010). The mental health benefits of work: Do they apply to poor single mothers? Social Psychiatry and Psychiatric Epidemiology, 45(1), 77-87.

Zainab.I, Wan Ibrahim. W.I, Asyraf HAR (2014). Counselling Services in Muslim Communal

Zaini, S. (2014). Hubungan Spiritualiti, Religiositi, Sokongan Sosial ke atas Kesihatan Mentaldalam kalangan Ibu Tunggal di Wilayah Persekutuan Kuala Lumpur. Unpublished PhD Thesis. Universiti Kebangsaan Malaysia, Bangi

Zaini, S. (2014). Hubungan Spiritualiti, Religiositi, Sokongan Sosial ke atas Kesihatan Mental dalam kalangan Ibu Tunggal di Wilayah Persekutuan Kuala Lumpur. Unpublished PhD Thesis. Universiti Kebangsaan Malaysia, Bang

Zainol, F. A., Daud, W. N. W., Abdullah, Z., \& Yaacob, M. R. (2014), Overcoming poverty through social entrepreneurship: A conceptual paper. International Business Research, 7(7), 183-188.

Zakaria Mohamad, Jasmi Abu Talib and Mazidah Mohd. Dagang, (2020) Effects of Visual Art Therapy on Cognitive Emotion Regulation and Anxiety of Single Mothers. International Journal of Management, 11 (6), pp. 891904

Zakaria Mohamad, Melati Sumari, Patricia Fenner and Siti Aishah Mohamad Noor, (2020) Understanding Emotional Experiences of Single Mothers using Narrative Group Therapy, International Journal of Management, 11 (7), pp. 203-213.

Zakaria Mohamad, Zuhda Husain, Jasmi Abu Talib, Raba'aton Adawiah Mohd Yusof, Fazliyaton Ramley, Mazidah Mohd Dagang, Nurul Atiqah Ab Raji \&amp; Marhaini Mohd Noor (2019). The Effectiveness of Arts Therapy Module on the Well-being of Single Mothers. Humanities \&amp; Social Sciences Reviews. 7:1. 441-449.

Zanalisa Mgt Mat Isa. (2012). Keberkesanan Pelaksanaan Program Latihan Kemahiran (I-KIT) Terhadap Ibu Tunggal di JPW Negeri Johor. Tesis Sarjana Muda yang tidak diterbitkan. Fakulti Pendidikan, UTM, Skudai. 